\title{
The Impact of External Contextual Factors on Teaching Candidates
}

Alexander S. Butler ${ }^{1}$

$\approx$ The formation of a teacher's identity is considered a dynamic process influenced by internal and external contextual factors. This article explores the impact that external contextual factors have on teacher candidates' identities by presenting the findings of an empirical qualitative study that investigated the relationship between teacher candidates' beliefs and their demonstrations and representations of teaching and learning on a nationally standardised portfolio assessment. Metaphor analysis and stimulated recall were used to explore this relationship. The study found that teacher candidates' teaching demonstrations while student teaching and representations of teaching found in a nationally standardised portfolio assessment were severely constrained by cooperating teachers and scripted curriculums. However, the study also found that candidates could articulate the differences between their beliefs about teaching and learning and their demonstrations and representations of teaching and learning. Candidates routinely made suggestions in the portfolio assessment to align their future teaching more closely to their metaphors for teaching. The study concluded that candidates did not change their beliefs but took up temporary teaching identities based on these findings. They found ways to navigate the assessment and their (teaching) context while remaining committed to their teaching identity and beliefs about good teaching. This article suggests how education system contexts impact the formation of teacher candidates' identities and what teacher education programmes need to do to strengthen candidates' identities in the face of negative external influences.

Keywords: beliefs about teaching and learning, student teachers, student teaching, teacher education, teacher identity

1 Teaching and Learning Department, Florida International University, United States of America; albutler@fiu.edu. 


\section{Vpliv zunanjih kontekstualnih dejavnikov na študente, ki se izobražujejo za učitelje}

Alexander S. Butler

$\approx$ Oblikovanje učiteljeve identitete je dinamičen proces, na katerega vplivajo notranji in zunanji kontekstualni dejavniki. Ta članek preučuje vpliv zunanjih kontekstualnih dejavnikov na identiteto študentov, ki se izobražujejo za učitelje. Predstavljene so ugotovitve empirične kvalitativne študije, izvedene na nacionalno standardizirani oceni portfolia, ki je raziskovala odnos med prepričanji študentov ter njihovimi prikazi in predstavitvami poučevanja in učenja. Za raziskovanje tega odnosa sta bila uporabljena analiza metafor in spodbujeno spominjanje. Študija je pokazala, da so študente pri demonstracijah poučevanja med študentskim poučevanjem in predstavitvah poučevanja, ki jih najdemo na nacionalno standardiziranem portfeljskem ocenjevanju, močno omejevali sodelujoči učitelji in predpisani učni načrti, vendar pa je študija pokazala tudi, da so študentje znali izraziti razlike med svojimi prepričanji o poučevanju in učenju ter svojimi demonstracijami/prikazi in predstavitvami poučevanja in učenja. Študentje so pri ocenjevanju portfolia redno podajali predloge, da bi svoje prihodnje poučevanje bolj uskladili s svojimi prispodobami poučevanja. V raziskavi je bilo ugotovljeno, da študentje niso spremenili svojih prepričanj, ampak so na podlagi teh ugotovitev prevzeli začasne identitete poučevanja. Našli so načine, kako usmerjati ocenjevanje in svoj (učiteljski) kontekst, hkrati pa so ostali zavezani svoji učiteljski identiteti in prepričanjem o dobrem poučevanju. Članek predlaga, kako konteksti izobraževalnega sistema vplivajo na oblikovanje identitet študentov in kaj mora biti storjeno na ravni programov za izobraževanje učiteljev, da bi okrepili identitete študentov zaradi negativnih zunanjih vplivov.

Ključne besede: prepričanja o poučevanju in učenju, študentje učitelji, študentsko poučevanje, izobraževanje učiteljev, identiteta učitelja 


\section{Introduction}

I was highly discouraged to do it because my teacher had a say on that. She said she didn't think it would benefit me because they don't do them ... Because she didn't do them, that was the biggest thing. I kept saying that this would be so much easier if everything was a small group, and she just saying, 'It's the end of the day. They barely focus. We don't always get to math enough.' It was her thing. I didn't agree with it ... that was the hardest thing about the edTPA [a nationally standardised portfolio assessment]. Your teacher is not on board... makes your life miserable. I had all these ideas for what I wanted to do, and kind of got shot down ... she was like, 'We don't do that.' She didn't want me to mess up her plans.

Meredith

Meredith said these things while reflecting on her student-teaching experience and how it related to her beliefs about teaching. It is clear that she felt constrained from enacting the teaching style she thought best because of her cooperating teacher. Her statements reveal a disjunction between the teacher she wanted to be and the one she was allowed to be. Alternatively, in other words, it revealed a dissonance between her beliefs about teaching and her practice in a particular context. It has often been suggested that cooperating teachers significantly impact the quality of teacher candidates' student teaching experience (e.g., Clarke et al., 2014; Cuenca, 2011). While this may be true, what is sometimes assumed is that cooperating teachers significantly impact teacher candidates' beliefs about teaching and their teaching identity. It may be that teacher candidates have beliefs that shape their teaching identities, yet they cannot enact or display this identity in their student teaching setting. In order to navigate these constraints, student teachers may assume temporary identities without changing their core beliefs to meet certain standards or expectations while also recognising how their actions within the temporary identity do not align with their beliefs about teaching and learning. This article analyses how educational contexts shaped preservice teachers' identities by investigating the relationship between student teachers' beliefs about teaching and learning and their evaluation of their representations of teaching and learning in their edTPA (Teacher Performance Assessment) portfolio, a nationally standardised licensure assessment for preservice teachers in the United States.

Teacher identity was considered a significant, if not vital, aspect of becoming a teacher (e.g., Britzman, 2003; Hammerness, 2006; Thomas \& Beauchamp, 2011) because it was considered to be closely linked to a teacher's 
practice (Wenger, 1998) and had the potential to reveal whether the values about teaching and learning the individual holds align with the goals of their teacher education programmes (Smagorinsky et al., 2004). Investigating teachers and preservice teachers' beliefs has been an important lens for studying teachers' identities because it has been considered either integral or related to a teacher's identity (Thomas \& Beauchamp, 2011; Smagorinsky et al., 2004) and has been found to have a similar impact on teachers' classroom decisions and behaviours (Fives \& Buehl, 2012; Nespor, 1987; Pajares, 1992). However, while the literature is clear that beliefs and actions are related (e.g., Richardson \& Placier, 2001), the literature also suggested beliefs have a complex and reciprocal relationship with one's practices (Buehl \& Beck, 2014). This complexity might exist because internal and external factors may cause incongruencies between beliefs and practices. To better identify these internal and external variables and the role they played in shaping participants' student teaching, the researcher relied on Burke's (1945) theory of human action and motivation. Most importantly, Burke's pentad helped identify who or what has the power to influence student teachers' practices and why they hold that power.

Burke (1945) introduced five elements for investigating human action and motives. These five elements included Act (what was done), Scene (where it was done), Agent (who did it), Agency (how it was done), and Purpose (why it was done). He organised the pentad as a heuristic in the shape of a star (see Figure 1). The heuristic explains the relation of the elements of the pentad to one another. In particular, Burke points out that the Scene is a container of sorts. It contains both the Act and the Agent. Though it impacts each of the components of the pentad, it directly impacts the Agent and the Act. He argued that because the Agent is contained by the Scene, the Agent takes on the attributes of the Scene.

Regarding the relation between the Scene and the Act, Burke suggested, 'there is implicit in the quality of a scene the quality of the action that is to take place within it' (pp. 6-7). The uptake of Burke's theory is that the Act will be consistent with the Scene because the Scene contains any potential Act. Therefore, the Scene limits or affords what the Agent can do and the Act can be. 


\section{Figure 1}

Burke's pentad showing the components impacting candidates' representations of teaching during student teaching

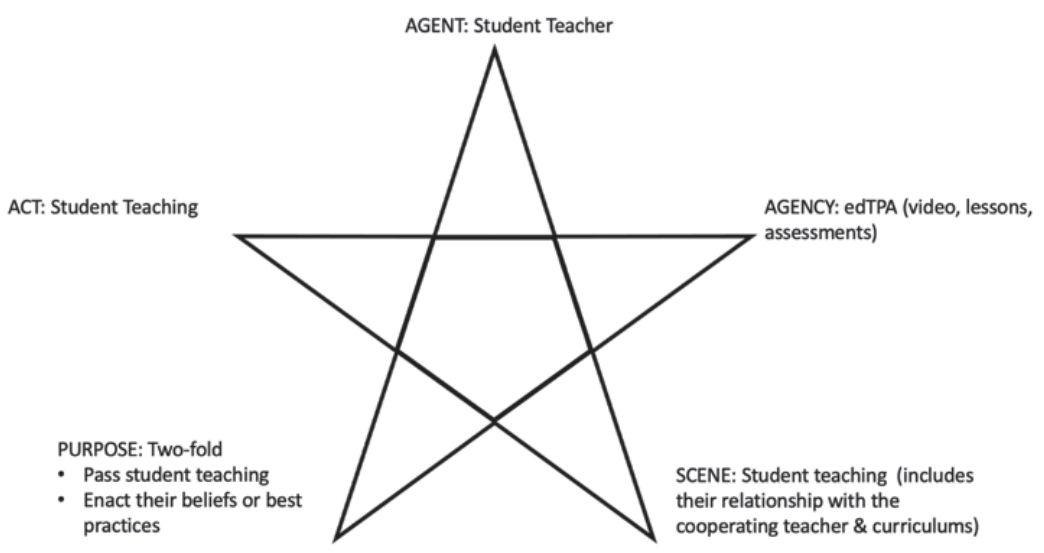

For example, Burke's theory helps explain why external factors, such as mentors, in this case cooperating teachers, are widely considered to influence (Cohen \& Galbraith, 1995), if not have the largest impact on teacher candidates' student teaching experiences and learning (e.g., Clarke et al., 2014; Cuenca, 2011). The candidates not only rely on the cooperating teacher because they have more experience, but because cooperating teachers have (Barrows, 1979, as cited in Veal \& Rikard, 1998, p. 108), or student teachers often presume (Smith, 2007) the cooperating teacher has, the power to shape what Burke labelled as the Scene. Similarly, when the cooperating teacher's Scenes are determined by prescribed curriculums, their Acts then are constrained, and it follows that a student teachers' Act would also be defined by the prescribed curriculum. While there may be cases where it is a good thing for the student teacher's Acts to be constrained by a Scene (e.g., when a student teacher enacts or plans methods not appropriate for their students), a Scene that does not allow an Agent to shape the Scene is particularly concerning considering Grossman et al.s (1999) suggestion that the social practices within the student teacher's context and the possible actions student teachers were able to choose from promoted a particular ideal and impacted a teacher's construction of a teaching identity. Thus, the possibilities a Scene affords student teachers as the Agent needs to be closely examined.

Given the potential of beliefs to shape student teachers' identities and actions and Burke's recognition of the role the Scene plays in shaping the Act and the Agent, the research questions below were investigated. 
1. What were student teachers' beliefs about teaching and learning?

2. How were student teachers' beliefs related to their representations and demonstrations of teaching in the edTPA?

3. Why were student teachers' beliefs and their representations and demonstrations of teaching aligned or misaligned in their representations and demonstrations of teaching in the edTPA?

4. How were student teachers' beliefs about teaching and learning impacted by their student teaching experience, including the edTPA?

\section{Methods and Analysis}

Data for this study were collected through two semi-structured interviews and participants' submission of their edTPA portfolio. The study had nine participants who were student teachers during the spring of 2019. The participants student taught in various $\mathrm{K}-12$ settings and content subjects in the midwestern United States. Three participants taught 6-12 grade. The other six participants taught elementary school $(\mathrm{K}-5)$. All participants were in their early twenties, had graduated from the same large research university teacher education programme, were white or white-passing, and had passed the edTPA on their first submission. Participants were selected through convenience and snowball sampling methods due to federal regulations restricting access to possible participants' contact information.

The first interview used metaphor analysis to uncover and explore participants' beliefs about teaching and learning using an adapted protocol from Munby (1984) and Fives and Buehl (2008). It occurred the summer after they completed their student teaching and had graduated from their teacher education programme. Metaphors are useful for exploring one's understanding of the world (Gurney, 1995), are often the most verbal and explicit expression of tacit beliefs, can act as evidence of preservice teachers' understanding of teaching and learning (Saban \& Saban, 2006), and can reveal teachers' construction of their professional reality (Munby, 1986, 1987). Participants were asked to create metaphors about teaching and were then asked questions about teaching and learning. The questions were used to help the researcher determine if participants' implicit beliefs about teaching and learning, as evidenced in the metaphors, were aligned with their explicit statements about teaching and learning. At the end of the interview, participants were asked to categorise their metaphor within one of Alger's (2009) six overarching metaphors. After the initial interview, the data was transcribed and inductively coded (Saldaña, 2014) to allow the data to speak for itself (Thomas, 2006). Analysis was an iterative process 
that identified inductive themes within the interview transcripts that were then compared to the participants' created metaphors and Alger's (2009) overarching metaphors. This, alongside the clustering of the inductive codes, helped determine the participant's prevalent beliefs about teaching and learning.

After the first interview, candidates emailed digital copies of their edTPA portfolio to the researcher that had been submitted to the university for assessment. It can be evaluated by Pearson or by licensed higher education institutions. The edTPA website describes the assessment as a 'performance-based, subject-specific assessment and support system ... [used] to emphasise, measure, and support the skills and knowledge that all teachers need from Day 1 in the classroom' (edTPA, n.d.). While edTPA does not claim to measure everything a candidate needs to be able to do competently before they enter the classroom, nor ask candidates to express everything they believe about teaching, it does ask candidates to represent in a snapshot what they can and will do in the classroom. The term 'representations' is used to identify how candidates depict teaching on the edTPA. Representations make visible the practices of a profession (Grossman et al., 2009). In the edTPA, these representations include their written responses and reflections to prompts provided by the edTPA (context for learning and commentaries), video clips giving visual evidence of the student teacher's teaching, and the artefacts from their lessons (including plans, worksheets, presentations, assessments, and feedback) submitted in their edTPA portfolio.

In preparation for the stimulated recall during the second interview, the researcher analysed participants' edTPA portfolios. The researcher marked a copy of participants' edTPA with specific questions or thoughts about the portfolio and looked for statements and ideas that seemed related to the themes found in participants' first interview. For example, the researcher looked for alignment or misalignment between candidates' beliefs and representations. Whether misalignment or alignment was identified, four excerpts were pulled from their edTPA portfolio for participants to read through. These excerpts were identified as places that the participants clearly discussed their teaching. During the second interview, participants were asked to participate in a stimulated recall, which Dempsey (2010) has suggested brought participants closer to the moment of when the action was produced; Marland and Osborne (1990) suggested could reveal the implicit theories and tacit beliefs of teachers and their principles, tactics, and role conceptions. Eight of the nine participants were former students who had strong rapport with the researcher. O'Brien (1993) and Tuckwell (1980) suggested that an elicitation technique like stimulated recall required strong rapport with participants so that they did not feel as if they were performing for the researcher. The more comfortable candidates felt, the more likely it was that 
they would be forthright in their interviews. The second interview adapted Tuckwell's (1980) stimulated recall protocol to discuss whether the excerpt was aligned or misaligned with their beliefs about teaching. When participants identified misalignment, they were asked how they would align their teaching and what it would require to align it with their beliefs.

When coding and analysing the second interview, the same process was used as with the first interview. Through iterative readings, inductive codes were created and thematised. Eventually, codes were categorised into three to eight themes. Once the coding of the second interview was finished, comparisons were drawn between participants' metaphors and beliefs about teaching and learning from the first interview with their stimulated recall in the second interview. Although this study cannot be used to make statistical generalisations because it did not use a more randomised sampling method, it has performed an in-depth analysis of the relationship between candidates' beliefs of teaching and learning, their representations on the edTPA, and their student teaching experience.

\section{Results}

Analysis of the data from the initial study demonstrated that participants experienced significant constraints when attempting to enact their beliefs in their student teaching contexts. The initial study investigated how the edTPA shaped participants' demonstrations and representations of teaching. However, in that investigation, the researcher found data suggesting participants faced significant constraints to practising their beliefs that the edTPA helped reveal. Furthermore, participants who experienced constraints external to the edTPA repeatedly stated they faced these throughout their student teaching. This article focuses on the participants who experienced external to the edTPA constraints throughout their student teaching and how this impacted their beliefs about who they were as teachers. In what follows, the researcher presents the findings to the research questions through participants' statements as they discussed their beliefs and their ability to demonstrate those beliefs in their student teaching.

\section{Participants' Beliefs}

After the first interview, the researcher found that participants had various beliefs about teaching and learning. Several participants identified more than one of Alger's (2009) overarching metaphors as being related to their created metaphor. For example, Gwen said she was torn between Teaching 
is Guiding and Teaching is Nurturing. At the beginning of the first interview, Gwen described the teacher as a compass. She defined a compass as an object a person uses 'to guide you in the right direction. It doesn't give you the exact coordinates. It just gives you a direction to go into.' The idea of nurturing was a central component of guiding because it was a supportive posture rather than a paternalistic posture. She emphasised that teachers were compasses that gave students direction but did not tell them their destination. Eventually, she decided her metaphor of a compass best fit Teaching is Nurturing, describing herself as 'watering it [students]. I am giving them the guidance and helping them grow into what they want to become.' While it was clear she liked aspects of Alger's Teaching is Guiding metaphor, she was concerned that the Teaching is Guiding metaphor expected the teacher to control where students went. Since Gwen felt that students needed to determine the direction of their growth, she chose the metaphor Teaching is Nurturing. The ability of participants, like Gwen, to nuance their beliefs and justify their choice of Alger's metaphor provided evidence that candidates knew what they believed about teaching and learning because they were able to identify and explain nuances in their metaphors.

\section{Identifying Alignment and Misalignment in their edTPAs}

In the second interview, when participants performed the stimulated recall with excerpts from their edTPA portfolios, participants consistently identified representations or demonstrations that did or did not align with their beliefs. For example, in the first interview Eliza, who student taught $7^{\text {th }}$ grade English, identified Teaching is Guiding as the overarching metaphor that her created metaphor fit. When she spoke in the first interview about teaching, she described herself as a guide because

I don't feel that I can ever tell someone something, and they're going to be like, 'Yes, absolutely.' I think people need to create their own meaning. In my classroom, they're trying to create meaning from the books I present to them, the articles we read, the writing assignments I have them do. In my classroom, I think I can facilitate that creating of meaning for both themselves and the world. I can incorporate books and articles that I think will be meaningful for my students themselves based on their interests or their place in life.

However, when Eliza was performing the stimulated recall in the second interview, she consistently pointed out that her representations and demonstrations in the edTPA and throughout her student teaching rarely guided students, nor was she able to 'incorporate books and articles that I think will 
be meaningful for my students.' For example, she pointed out during the stimulated recall that she did not have the time to help her student make 'connections between their own experiences and the history of America' because the prescribed curriculum moved too quickly. Although she did identify other places during the stimulated recall procedure where her representation aligned with her belief that Teaching is Guiding, these occurrences were found in representations in which she described herself as having more autonomy. For example, when reading through her writing about the feedback given to students in Task 3, she described her demonstration of feedback as aligned with her belief that Teaching is Guiding and that giving feedback was one of the spaces she could represent her beliefs.

I tried to provide feedback that would guide them in their thinking. Go a little further in their thought process ... even if we didn't have as much time to do so, I tried to do it with their feedback.

Eliza's ability to identify her beliefs and where she did or did not incorporate them in the edTPA is representative of all of the participants in this study. Participants were able to identify their beliefs when asked to reflect on their practices, either by reading through their lesson plans, reading through reflections of their teaching, or examining artefacts from their teaching. In addition, they were asked whether they sought to enact their beliefs when given the opportunity.

\section{Constraints}

Eliza's thoughts above on the feedback she gave students alluded to her not having much time to guide them in their thinking. When asked why she did not have the time to guide students, Eliza described a prescribed curriculum provided by the school that significantly constrained her demonstration of teaching. Two other participants in the study identified prescribed or scripted curriculums as constraining their demonstrations of teaching; two more described their cooperating teacher as negatively constraining their demonstrations of teaching (See Table 1). One participant (Nick) specifically mentioned both cooperating teachers and the curriculum as not constraining to him. He not only had full control of his curriculum but felt supported by his cooperating teachers. He described feeling free to demonstrate and represent teaching as he saw best. His experience provided a powerful counterexample to the other participants of how a student-teacher was given space to attempt to enact their beliefs and their impact on their evaluation of their teaching demonstrations in the edTPA. The depth of cooperating teachers and prescribed or scripted 
curriculums as constraints was particularly noticeable in the sections of the edTPA where candidates were asked to propose changes to their teaching.

Table 1

Candidates' constraints in representing their beliefs

\begin{tabular}{lcc}
\hline Participants & Cooperating Teachers & Prescribed or Scripted Curriculum \\
\hline Eliza & & $\mathrm{X}$ \\
\hline Gwen & $\mathrm{X}$ & \\
\hline Lucy & & $\mathrm{X}$ \\
\hline Maria & & $\mathrm{X}$ \\
\hline Meredith & $\mathrm{X}$ & \\
\hline Nick & & \\
\hline
\end{tabular}

\section{Making Adjustments}

The edTPA asked student teachers to analyse and suggest changes to their teaching in several sections. In these sections, participants routinely suggested adjustments to their teaching to bring their demonstrations and representations of teaching in the edTPA into alignment with their beliefs. For example, Meredith, who student taught in kindergarten, spoke about teaching in the first interview as juggling. When constructing her metaphor, she said, 'everyone is coming in so many different ways. So many different levels. ... you have to think in twenty-one or up to thirty different ways. So, you can reach all these kids.' Later in the first interview, she reemphasised the idea of differentiation by saying part of juggling 'is knowing how to reach all learners.' Despite her belief in being a teacher who recognised students' different needs and levels, it was clear from the introductory quote to this article that Meredith felt constrained to enact her beliefs in her student teaching context. When asked by the edTPA in Task 2: Instruction Commentary Part 5: Analysing Teaching about changes she would make to her teaching demonstrations included in the edTPA, she wrote specifically about incorporating centres as a pedagogical tool because it allowed for small group instruction and the individualisation of instruction for each student. When the researcher asked why she did not include centres in her lessons if she believed they would have been effective in promoting students' learning, she described how her cooperating teacher would not let her use centres (See the introductory quote to this article). When prompted by the edTPA to suggest changes to her teaching, Meredith clearly realigned her desired practices with her beliefs expressed in the first interview about teaching and learning. 
Maria made a similar move to realign her future practices with her beliefs in her writing for the edTPA. In the first interview, Maria had described herself as a guide who worked alongside students to help them grow and learn. She specifically identified the PACE Model (Adair-Hauck \& Donato, 2002) and Krashen's (1992) comprehensible input hypothesis as representative methods of her beliefs. However, as the researcher analysed her edTPA portfolio, it was clear that her representations and demonstrations of teaching did not align with her beliefs. It was not until reading through Task 2: Instruction Commentary Part 5, the section in which student teachers were asked to analyse their teaching and suggested changes, that her beliefs from the first interview reappeared. In this section of the edTPA, Maria suggested she should have used Krashen's comprehensible input hypothesis as the framework for her lessons because students 'would be able to grow in their interpretive and communicative abilities without relying on English.' When asked why she had not incorporated Krashen's idea in her initial teaching, she described not being able to enact Krashen's hypothesis because, 'I had to make sure it [my teaching] fits into their [the school's] curriculum' and 'there were times when I could not use my style of teaching because I had to make sure students were still learning what they needed to in order to keep up with the curriculum.' There is a clear sense that Maria thought her students needed to move at a slower pace and needed a greater and different form of scaffolding than the curriculum provided to more effectively develop their language skills. Her recognition of the need for this change and her statement suggested a change that would not only bring her into closer alignment with Krashen's comprehensible input theory, which deemphasises memorisation of rules and grammatical correctness and emphasises a more natural language learning environment but also aligned her teaching with the beliefs about teaching she expressed in the first interview.

As Meredith, Maria, and Eliza's examples demonstrate, their cooperating teachers or curriculums impacted their entire portfolios and their entire student teaching experience. Even Nick mentioned these two shapers of the student teaching context. However, he mentioned them in positive ways because he had control over the curriculum and he had supportive cooperating teachers (he had two cooperating teachers). When asked about the changes he suggested to his teaching, he commented that he had 'missed an opportunity' to support student learning better and that 'nothing was preventing me from doing that,' implementing the changes in his student teaching context. In fact, he said that 'If I had a concern while I was teaching or I needed to reflect on what went well or didn't go well, they were pretty open to talking and critiquing or telling me what did or didn't go well.' In the instance where he felt he had 
'missed an opportunity', he sat down with his cooperating teachers right after the lesson to ask them what he could have done better because he felt he had not supported the students' learning well. He described their feedback as helpful and supportive. The study found a clear difference between participants' who had the autonomy to shape their student teaching and those who did not when explaining why their edTPA was aligned or not aligned with their beliefs about teaching.

This study found that:

1. Nine out of nine participants were able to identify when their demonstrations and representations of teaching were not aligned to their beliefs expressed in the first interview.

2. Nine out of nine participants realigned their representations to their beliefs in the edTPA sections, asking them to reflect on their teaching and suggest adjustments.

3. Cooperating teachers or prescribed curriculums significantly impacted participants' ability to enact their beliefs because they constrained their entire student teaching experience.

4. Participants' beliefs did not seem to be impacted by their student teaching experience because they consistently suggested changes to their teaching that would realign their representations of their teaching in their edTPA portfolio to their beliefs expressed in the first interview.

\section{Discussion}

At first blush, the incongruence between what the participants believed and what they demonstrated during their student teaching might lead some to suggest that beliefs do not strongly correlate with teachers' practices. However, the findings in this study should not discount the value of studying beliefs. Rather, it reiterates Fives and Buehl's (2012) exhortation to investigate why the incongruence existed. This study found that an incongruence existed because participants were placed in contexts that constrained their teaching in ways that prevented them from aligning their practices with their beliefs. Candidates did not change their beliefs but took up temporary teaching identities. They conformed to their (teaching) context while remaining committed to their teaching identity and beliefs about good teaching. For example, Meredith did not use centres as a method for differentiation in her classroom because the cooperating teacher told her she could not use centres. Meredith followed the cooperating teacher's desires despite believing centres would have helped her be a more effective teacher. These constraints did not allow participants 
to shape their teaching as the research on the relationship between beliefs and teacher practices expected. Burke's (1945) pentad helps identify the cause of the disconnect between participants' beliefs and their actions.

While it may have been possible for participants to pushback against the Scene by using the edTPA (e.g., Ahmed, 2019), it is not likely that a student teacher, who is already attempting to navigate a stressful experience (DarlingHammond, 2006), has the skills to subvert their context or motivation to take a risk that might make their student teaching more difficult (Smith, 2007) without significant support and training from teacher educators (Anderson \& Stillman, 2013). In instances in which participants did not have a more flexible or supportive Scene, they could not perform actions or embody beliefs outside of what the Scene allowed. Evidence for this conclusion is based on the stimulated recall in which participants explained suggested changes in their edTPA representations that would have realigned their teaching with their beliefs. Burke's (1945) theory helped explain participants' actions. The Scenes caused the Agents and the Acts to take on the attributes of the Scenes. As Burke suggested, and this study found, participants made pedagogical and content decisions consistent with the Scene rather than with their beliefs. For example, Gwen suggested that when discussing the difference between herself and her cooperating teacher when teaching visualisation strategies to their students, 'the theatre in me would say for visualising, ok, you create it with your own body'. She identified as a teacher who has 'theatre' within her, and it is something she planned on using in her classroom but could not use during her student teaching. In fact, when the researcher followed up with Gwen during the fall of her first year of in-service teaching, she shared a story about how she had incorporated Reader's Theatre in her classroom.

I was the only class that did it, and my kids love it. Now they want to do it at the end of every unit. My principal was really excited about it because that's a tough thing for kids to do, to speak in front of other classes. I had multiple classes come in and watch the performance. There were a lot of mistakes, but that's something they need to learn from. It's reading, it's comprehending what the story is about. It's the practising, the teamwork. There's so many things within it that I really enjoy doing with them, and they liked it.

Her inability to use the 'theatre in [her]' during her student teaching clearly did not impact her beliefs about what it meant to be a good teacher when she had control over her classroom. Gwen's experience during her firstyear highlights Grossman et al.s (1999) suggestion that student teachers often 
struggle to develop or enact their own identities until they are set free from their contextual constraints, which often does not happen until their first year of teaching.

The researcher agrees with Treadwell et al.s (2017) suggestion that candidates need to be placed in supportive student teaching contexts in which they can practice the skills learned and dispositions acquired during college. Programmes cannot ignore the important role student teachers' contexts play in their ability to practice and reveal who they are as teachers. Student teachers like Nick, who had supportive cooperating teachers and were given freedom over their curriculum, provide an example of how student teachers can grow into and reflect upon their practices and their ability to implement their beliefs and identities when placed in positive settings. These results are important for teacher educators and programmes to consider because constraining contexts forced candidates to make compromises in ways that were not aligned with their beliefs about teaching. Rather, participants took up temporary teaching identities in order to navigate their student teaching experience. When participants who had been placed in constraining contexts had the opportunity to critique and make suggestions to change their teaching in the edTPA, they took the opportunity to suggest practices and theories that were aligned with their beliefs about teaching and learning. Participants' representations of teaching in the edTPA were not aligned with their beliefs about teaching and learning when they were student teaching in constraining contexts. This study seeks to compel teacher education programmes to re-evaluate the student teaching experience and the importance of assessing preservice teachers' beliefs and their identities. Doing so might give programmes a better understanding of the teachers they produce and how to better support student teachers.

\section{Conclusion}

Recognising the distinction between who student teachers want to be and who they are given space to be in the classroom is an important consideration for understanding teacher candidates' identities. It is also important for teacher education programmes as they consider how to evaluate preservice teachers' preparedness to enter the classroom. The study reminds teacher education programmes that one of the roles of teacher education, including the student teaching experience, is to give teacher candidates space to try different methods and experiments (Grossman et al., 1999). During her first interview, Eliza also pointed this out when she said, 'Well, that's what teaching is. You try something; next time you visit it, you tweak it, and keep tweaking it.' Student 
teachers need to be in settings where they can practice enacting their beliefs in supportive student teaching contexts. This means ensuring student teachers are not constrained by prescribed or scripted curriculums and have supportive cooperating teachers who are aligned with the university's teacher education identity. To do otherwise might cause student teachers to assume temporary identities that do not allow them to practice how to be the teacher they want to be nor for the university and cooperating teacher to truly know if the studentteacher is ready for the classroom.

One way to address this concern is by making cooperating teachers a larger part of the teacher educator community (Anderson \& Stillman, 2013). This might include having the triad (cooperating teacher, university supervisor, and teacher candidate) sit down together and build common goals and objectives for the student teaching experience. These meetings could include eliciting the student teachers' beliefs about teaching and learning and how they would like to incorporate them into their student teaching practice. Additionally, universities could do a better job placing students in supportive contexts by interviewing districts, schools, and cooperating teachers to ensure prescribed scripted curriculums are not being used. Teacher education programmes could also move to provide better training for cooperating teachers on how to mentor student teachers and build relationships that help the student-teacher develop their own teacher identity (Walkington, 2005). Finally, incorporating cooperating teachers, schools, and districts into the university's community might help align the Scenes candidates' experiences in the classroom and the field.

Since beliefs can filter, frame, and guide action, programmes seeking to assess their effectiveness in preparing candidates to enter the field might want to investigate candidates' beliefs rather than merely their student teaching demonstrations because, as this study found, participants' student teaching was likely to mirror their context rather than their beliefs. This investigation by teacher educators and programmes will not only help them understand if they are producing candidates who embody the programme's beliefs about effective teaching and teaching identities, but it will also give a baseline to evaluate student teachers' ability to enact those beliefs. If misalignment exists among the programme's beliefs, the candidate's beliefs, or/and the candidate's representation of teaching, then programmes can help candidates recognise the gaps between their beliefs and practices to promote the cognitive dissonance that can stimulate teacher change (Borg, 2018). In addition, Tillema (2000) found that candidates who partook in reflective practices after their student teaching experience were less likely to revert to their initial beliefs about teaching. This suggests that teacher education programmes should consider implementing 
purposeful debriefing sessions with candidates after their student teaching experience. Similar to the triad meetings at the beginning of candidates' student teaching experiences mentioned above, these debriefing sessions would further develop the relational and collective agency Ahmed (2019) suggested candidates needed to resist or subvert problematic constraints. Besides recognising the individual's constraining factors, finding misalignment should also lead programmes to evaluate themselves. Are programmes incubators for external factors constraining candidates' ability to enact their beliefs?

One limitation of this study is that the findings cannot inform the reader if the beliefs and the connected actions were or would have been considered best practices. Although each of the participants passed their edTPA on their first attempt and most constructed a metaphor that was aligned with their responses to questions asking them about their explicit beliefs about teaching and learning, this only suggests that participants knew their own beliefs well. It does not provide information that informs teacher educators whether these beliefs were best practices. The results provided evidence that participants' beliefs were consistent with what they suggested they should have done, but not whether teacher educator programmes would have approved of these practices.

Based on these findings, the study concluded that candidates did not change their beliefs but took up temporary teaching identities. They found ways to navigate their teaching context while remaining committed to their teaching identity and beliefs about good teaching. This article suggests how education system contexts impact the formation of teacher candidates' identities and what teacher education programmes need to do to strengthen student teachers' ability to enact their beliefs during their student teaching experience.

\section{References}

Adair-Hauck, B., \& Donato, R. (2002). The PACE model: A story-based approach to meaning and form for standards-based language learning. The French Review, 76(2), 265-276.

Ahmed, K. S. (2019). Against the script with edTPA: Preservice teachers utilise performance assessment to teach outside scripted curriculum. Urban Education, 1-31. https://doi.

org/10.1177/0042085919873689

Alger, C. L. (2009). Secondary teachers' conceptual metaphors of teaching and learning: Changes over the career span. Teaching and Teacher Education, 25(5), 743-751. https://doi.org/10.1016/j. tate.2008.10.004

Anderson, L., \& Stillman, J. (2013). Making learning the object: Using cultural historical activity theory to analyze and organize student teaching in urban high-needs schools. Teachers College Record, 115(3), 1-36. 
Beauchamp, C., \& Thomas, L. (2009). Understanding teacher identity: An overview of issues in the literature and implications for teacher education. Cambridge Journal of Education, 39(2), 175-189. https://doi.org/10.1080/03057640902902252

Borg, S. (2018). Teachers' beliefs and classroom practices. In P. Garrett \& J. M. Cots (Eds.), The Routledge handbook of language awareness (pp. 75-91). Routledge.

Britzman, D. P. (2003). Practice makes practice: A critical study of learning to teach. (Rev. ed.). State University of New York.

Buehl, M. M., \& Beck, J. S. (2014). The relationship between teachers' beliefs and teachers' practices. In H. Fives \& M. Gregoire Gill (Eds.), International handbook of research on teachers' beliefs (pp. 74-91). Routledge.

Burke, K. (1945). A grammar of motives. Prentice-Hall.

Clarke, A., Triggs, V., \& Nielsen, W. (2014). Cooperating teacher participation in teacher education: A review of the literature. Review of Educational Research, 84(2), 163-202. https://doi. org/10.3102/0034654313499618

Cohen, N. H., \& Galbraith, M. W. (1995). Mentoring in the learning society. New Directions for Adult and Continuing Education, 66, 5-14. https://doi.org/10.1002/ace.36719956603

Cuenca, A. (2011). The role of legitimacy in student teaching: Learning to "feel" like a teacher. Teacher Education Quarterly, 38(2), 117-131. http://www.jstor.org/stable/23479696

Darling-Hammond, L. (2006). Constructing 21st-century teacher education. Journal of Teacher Education, 57(3), 300-314. https://doi.org/10.1177/0022487105285962

Dempsey, N. P. (2010). Stimulated recall interviews in ethnography. Qualitative Sociology, 33(3), 349-367. https://doi.org/10.1007/s11133-010-9157-X edTPA. (n.d). About edTPA. edTPA http://www.edtpa.com/pageview.aspx?f=gen_aboutedtpa.html Fives, H., \& Buehl, M. M. (2008). What do teachers believe? Developing a framework for examining beliefs about teachers' knowledge and ability. Contemporary Educational Psychology, 33(2), 134-176. https://doi.org/10.1016/j.cedpsych.2008.01.001 Fives, H., \& Buehl, M. M. (2012). Spring cleaning for the 'messy' construct of teachers' beliefs: What are they? Which have been examined? What can they tell us? In K. R. Harris, S. Graham, T. Urdan, J. M. Royer, \& M. Zeidner (Eds.), APA educational psychology handbook: Vol. 2. Individual differences and cultural and contextual factors (pp. 471-499). American Psychological Association. https://doi.org/10.1037/13274-019 Grossman, P. L., Smagorinsky, P., \& Valencia, S. (1999). Appropriating tools for teaching English: A theoretical framework for research on learning to teach. American Journal of Education, 108(1), 1-29. https://doi.org/10.1086/444230

Grossman, P., Compton, C., Igra, D., Ronfeldt, M., Shahan, E., \& Williamson, P. W. (2009). Teaching practice: A cross-professional perspective. Teachers College Record, 111(9), 2055-2100.

Gurney, B. F. (1995). Tugboats and tennis games: Conceptions of teaching and learning revealed through metaphors. Journal of Research in Science Teaching, 32(6), 569-583.

Hammerness, K. (2006). Seeing through teachers' eyes: Professional ideals and classroom practice. Teachers College Press. 
Krashen, S. (1992). The input hypothesis: An update. In J. E. Alatis (Ed.), Georgetown University round table on languages and linguistics (GURT) 1991: Linguistics and language pedagogy: The state of the art. (pp. 409-431). Georgetown University Press.

Marland, P., \& Osborne, J. (1990). Classroom theory, thinking, and action. Teaching \& Teacher Education, 6(1), 93-109. https://doi.org/10.1016/0742-051X(90)90010-3

Munby, H. (1984). A qualitative approach to the study of a teacher's beliefs. Journal of Research in Science Teaching, 21(1), 27-38. https://doi.org/10.1002/tea.3660210104

Munby, H. (1986). Metaphor in the thinking of teachers: An exploratory study. Journal of Curriculum Studies, 18(2), 197-209. https://doi.org/10.1080/0022027860180209

Munby, H. (1987). Metaphor and teachers' knowledge. Research in the Teaching of English, 21(4), 377-385. http://www.jstor.org/stable/40171124

Nespor, J. (1987). The role of beliefs in the practice of teaching. Journal of Curriculum Studies, 19(4), 317-328. https://doi.org/10.1080/0022027870190403

O’Brien, J. (1993). Action research through stimulated recall. Research in science education, 23(1), 214-221. https://doi.org/10.1007/BFo2357063

Pajares, M. F. (1992). Teachers' beliefs and educational research: Cleaning up a messy construct. Review of Educational Research, 62(3), 307-332. https://doi.org/10.3102/00346543062003307 Richardson, V., \& Placier, P. (2001). Teacher change. In V. Richardson (Ed.), Handbook of research on teaching (4th ed., pp. 905-947). American Educational Research Association.

Saban, A., Koçbeker, B. N., \& Saban, A. (2006). An investigation of the concept of teacher among prospective teachers through metaphor analysis. Educational Sciences: Theory \& Practice, 6(2), 509-522.

Saldaña, J. (2014). Thinking qualitatively: Methods of mind. Sage Publications.

Smagorinsky, P., Cook, L. S., Moore, C., Jackson, A. Y., \& Fry, P. G. (2004). Tensions in learning to teach: Accommodation and the development of a teaching identity. Journal of Teacher Education, 55(1), 8-24. https://doi.org/10.1177/0022487103260067

Smith, E. R. (2007). Negotiating power and pedagogy in student teaching: Expanding and shifting roles in expert-novice discourse. Mentoring \& Tutoring, 15(1), 87-106. https://doi. org/10.1080/13611260601037405

Thomas, D. R. (2006). A general inductive approach for analysing qualitative evaluation data. American Journal of Evaluation, 27(2), 237-246. https://doi.org/10.1177/1098214005283748 Tillema, H. (2000). Belief change towards self-directed learning in student teachers immersion in practice or reflection on action. Teaching and Teacher Education, 16(5-6), 575-591. https://doi. org/10.1016/So742-051X(oo)ooo16-o

Thomas, L., \& Beauchamp, C. (2011). Understanding new teachers' professional identities through metaphor. Teaching and Teacher Education, 27(4), 762-769. https://doi.org/10.1016/j.tate.2010.12.007 Treadwell, S. M., Cameron, J. L., \& Manson, M. (2017). edTPA and physical education: Tips for success for all stakeholders. Journal of Physical Education, Recreation \& Dance, 88(5), 39-45. https:// doi.org/10.1080/07303084.2017.1294511 
Tuckwell, N. B. (1980). Stimulated recall: Theoretical perspectives and practical and technical considerations. University of Alberta.

Veal, M. L., \& Rikard, L. (1998). Cooperating teachers' perspectives on the student teaching triad. Journal of Teacher Education, 49(2), 108-119. https://doi.org/10.1177/0022487198049002004 Walkington, J. (2005). Becoming a teacher: Encouraging development of teacher identity through reflective practice. Asia-Pacific Journal of Teacher Education, 33(1), 53-64. https://doi. org/10.1080/1359866052000341124

Wenger, E. (1998). Communities of practice. Cambridge University Press.

\section{Biographical note}

Alexander S. Butler, PhD, is a Visiting Assistant Professor of social studies education in the Teaching and Learning Department at Florida International University, Miami, FL, United States. His research interests include pre-service teachers' beliefs about teaching and learning, the way k-12 students' identities are shaped by certain social studies discourses, and how cartographic representations shape students' perceptions about the world. 